\title{
PENGEMBANGAN LEMBAR KERJA SISWA BERBASIS PENDEKATAN SAINTIFIK DALAM MATERI GARIS SINGGUNG LINGKARAN KELAS VIII
}

\author{
${ }^{1}$ Siti Habibatul Masruroh, ${ }^{2}$ Anas Ma'ruf Annizar, ${ }^{3}$ Novi Iffatul Azizah, ${ }^{3}$ Okta Ridha \\ Kamila \\ ${ }^{1,2,3}$ IAIN Jember, Jl. Mataram No.1, Karang Miuwo, Mangli, Kec. Kaliwates, Kabupaten Jember, Jawa Timur \\ 68136 \\ e-mail: anasannizar28@gmail.com
}

\begin{abstract}
Abstrak
Penelitian ini bertujuan untuk mengembangkan lembar kerja siswa menggunakan pendekatan saintifik pada materi garis singgung lingkaran kelas VIII. Penelitian ini merupakan penelitian pengembangan model Thiagarajan yang biasanya dikenal dengan model 4D yaitu meliputi: (1) pendefinisian (define). (2) perancangan (design). (3) pengembangan (develop). (4) penyebaran (disseminate) . Tetapi oleh peneliti di modifikasi menjadi 3D yaitu belum melakukan langkah penyebaran (disseminate) sebab keterbatasannya waktu. Dari penelitian ini skor hasil tes belajar siswa diperoleh 4 atau $80 \%$ siswa dinyatakan tidak tuntas dan 2 atau $20 \%$ siswa dinyatakan tuntas secara individual, adanya siswa yang masih dibawah KKM dimungkinkan pada waktu pembelajaran siswa masih belum mendalami pokok bahasan serta belum mengerti karena siswa tersebut tidak fokus.
\end{abstract}

Kata Kunci: Lembar Kerja Siswa, Pendekatan Saintifik, Garis Singgung Lingkaran

\begin{abstract}
This study aims to develop student worksheets using a scientific approach to the material tangent to a circle in class VIII. This research is a research on the development of the Thiagarajan model which is usually known as the 4D model, which includes: (1) definition ( define). (2) design (design). (3) development (develop). Spread (disseminate). But by the researchers it was modified into $3 \mathrm{D}$, that is, it has not carried out dissemination steps (disseminate). because of time constraints. From this study, the student learning test scores obtained 4 or $80 \%$ of students were declared incomplete and 2 or $20 \%$ of students were declared complete individually, the existence of students who are still below the KKM is possible at the time of learning students still do not explore the subject matter and do not understand because the student is not focused.
\end{abstract}

Keywords: Student Worksheet, Scientific Approach, Tangent to Circle

\section{PENDAHULUAN}

Menurut Undang - undang No. 20 tahun 2003 pendidikan merupakan upaya yang sudah direcanakan dalam memenuhi situasi pada saat pembelajaran yakni siswa aktif dalam proses pembelajaran sehingga sisa mampu mengembangkan kemampuannya untuk mempunyai 'kemampuan spiritual dalam beragama, mengendalikan diri sendiri, berkepribadian, cerdas, tingkah laku yang baik, keterampilan yang penting bagi dirinya sendiri. Persoalan didalam pendidikan masih berhubungan dengan persoalan dalam pembelajaran. Pembelajaran adalah suatu faktor yang keterlaksanaan didalam pendidikan 
maka kualitas pendidikan juga masih berhubungan dengankualitas pembelajaran. Dalam pelaksanaan kegiatan pembelajaran yang ada pada sekolah mencakup bermacam - macam ilmu pengetahuan, salah satunya yaitu ilmu matematika. Matematika merupakan suatu ilmu yang memiliki kedudukan yang berperan penting yang ada pada disiplin ilmu serta meningkatkan pola pikir siswa. (BSNP, 2006).

Matematika merupakan salah satu cara yang digunakan dalam mendapatkan penyelesaian dari persoalan pada saat manusia hadapi misalkan, salah satu cara untuk mengetahui penggunaan media informasi, memanfaatkan suatu ilmu untuk mengetahui bentuk dan ukuran, memanfaatkan ilmu yang berkaitan dengan menghitung, serta yang sangat diperlukan yakni memikirkan terhadap dirinya sendiri padasaat melihat serta dalam melakukan ikata.(Hasratuddin, 2013; Annizar dkk, 2020).

Materi garis singgung lingkaran merupakan salah satu pembahasan dalam matematika. Mempelajari materi ini sangat penting karena materi ini berkaitan dengan materi lainnya dan materi ini juga berhubungan dengan kehidupan sehari - hari salah satunya yakni rantai sepeda motor. Namun materi ini dalam kurikulum 2013 tidak ada pada KD dijenjang SMP. Padahal materi garis singgung lingkaran masih ada pada kompetensi khusus di jenjang SMA. Kebijakan ini kurang tepat, karena misalkan seorang siswa tidak menerima pelajajaran ini pada waktu SMP maka seorang siswa jika sudah ada dijenjang SMA nantinnya akan sulit dalam mempelajarinya. (Machin, 2016; Annizar \& Zahro, 2020).

Pendekatan saintifik merupakan suatu kegiatan belajar mengajar dimana siswa menyelesaikan suatu permasalahan dalam bentuk kerja kelompok, yang meliputi pengumpulan data untuk medapatkan informasi dan dengan berfikir kritis dan kreatif siswa diharapkan dapat menyampaikan informasi dengan baik sehingga siswa dapat memahaminya. Pendekatan saintifik berguna untuk membinbing kepekaan siswa dalam menghadapi masalah yang ada dilingkungannya, dengan menggunakan pendekatan saintifk murid akan terbiasa dalam menanya, berfikkir, berkomunikasi,mengumpulkan data, serta siswa akan aktif pada saat pembelajaran (Komang, 2020; Annizar \& Arifin, 2021).

Berdasarkan Permendikbud No. 65 Tahun 2013 tentang langkah - langkah dalam menggunakan pendekatan saintifik yaitu:

1. Mengamati

Dalam kegiatan mengamati lembar kerja siswa ini yakni masalah yang diamati yakni meliputi pokok bahasan garis singgung lingkaran yakni mengamati konsep garis singgung persekutuan dua lingkaran bagaian dalam dan luar. 
2. Menanya

Menuntut siswa agar bertanya pada saat pembelajaran agar siswa juga dapat berpendapat

3. Mengupulkan informasi

Aktivitas siswa dalam mencoba nampak saat pertemuan, ketika seorang siswa melakukan aktivitas yang ada di LKS. Bahan ajar yang telah dikembangkan diberikan aktivitas kepada siswa yang dituntut untuk dilakulakukannya percobaan membaca dari sumber lain, meneliti objek/kejadian, kegiatan , dan wawancara dengan koresponden.

4. Menalar

Aktivitas menalar bisa dari cara siswa dalam menyelesaikan pertanyaan yang diberikan, karena dengan diberikannya pertanyaan siswa di tuntut untuk dapat mengiterpresentasikan bermacam-macam ide dan sistematis dan berpikir logis untuk menjawab masalah yang di berikan.

5. Mengkomunikasikan

Kegiatan mengkomunikasikan dalam pengembangan LKS merupakan tindakan dimana siswa menyelesaikan dan menyimpulkan permasalahan yang ada di LKS.

Lembar kerja siswa (LKS) melalui pendekatan ilmiah atau pendekatan saintifik diinginkan bisa membantu siswa dalam memahami materi garis singgung lingkaran dan memberikan fasilitas bagi siswa dalam pembelajaran serta siswa diharapkan aktif dalam aktifitas mengamati, menanya, mencari informasi, menalar, dan mengkomunikasikan.

\section{METODE PENELITIAN}

Penelitian ini menggunakan model pengembangan Thiagarajan, yang biasanya dikenal dengan model pengembangan 4D. Model pengembangan 4D yaitu sebuah penelitian yang menerapkan empat golongan yakni (1) pendefinisian (define), (2) merancang (design), (3) pengembangan (develop), (4) menyebarkan ( disseminate).

\section{Pendefinisian (define)}

Fase ini bertujuan untuk menentukan pada saat pembelajaran. Define disini memiliki empat tahap yang meliputi: (a) analisis awal yang pertama dan terakhir memiliki tujuan untuk menentukan persoalan dasar didalam mengembangan instrumen dalam pembelajaran. (b) menganalisis murid memiliki tujuan untuk mengetahui karakter murid yakni sama dengan perencanaan dalam pembelajaran. (c) analisis konsep yaitu bertujuan untuk memutuskan inti pada satuan pembelajaran. (d) analisis tugas yang 
bertujuan untuk memutuskan tujuan dalam pembelajaran ketika hendak diperoleh siswa. tujuan pembelajaran yang akan dicapai siswa.

2. Perencanaan (design)

Pada fase ini bertujuan untuk mendesain instrumen dalam pembelajaran. Tahap perencanaan ini mempunyai tiga tahap yang meliputi: (a) perancangan awal yang bertujuan untuk mendesain aktivitas yang dilakukan sebelum uji coba. (b) memilih instrumen yang bertujuan untuk menentukan instrumen dengan materi yang akan diajarkan. (c) memilih format yang bertujuan untuk merancang isi dan strategi dalam pembelajaran.

3. Pengembangan (develop)

Fase ini berkaitan dengan validasi hasil produk yang akan dikembangkan. LKS yang dikembangkan divalidasi terlebih dahulu oleh para ahli. Untuk mengetahui sudah valid tidaknya modul pembelajaran yang akan dikembangkan.

4. Penyebaran (disseminate)

Pada fase ini bertujuan untuk menguji efektifitas pengguna perangkat hasil pengembangan pada skala yang luas. Data yang digunakan untuk menentukan ke validan LKS menggunakan data kuantitatif yang meliputi, tidak setuju, kurang setuju, setuju dan sangat setuju. Untuk menghitung presentasenya dapat dihitung dengan rumus berikut:

$$
\text { Tingkat Validitas } \frac{\text { skor yang diperoleh }}{\text { skor tertinggi }} \times 100 \%
$$

\section{Subjek Penelitian}

Subjek dalam percobaan yakni dari kelas VIII sebanyak 30\%. Selanjutnya dipilih secara acak 6 anak sebagai kelas uji coba lapangan. 1 orang guru yang melaksanakan pembelajaran menggunakan perangkat yang dikembangkan.

$$
\text { Tingkat Validitas } \frac{\text { skor yang diperoleh }}{\text { skor terting } i} \times 100 \%
$$

Tabel 1. Interpretasi Data Validitas Modul berbasis Multikultural

\begin{tabular}{ll}
\hline Interval & Kriteria \\
\hline $81 \%-100 \%$ & Sangat Valid \\
$61 \%-80 \%$ & Valid \\
$41 \%-60 \%$ & Cukup Valid \\
$21 \%-40 \%$ & Kurang Valid \\
$0 \%-20 \%$ & Tidak Valid \\
\hline
\end{tabular}


Analisis nilai rata-rata yang didapatkan dari angket siswa ini dikembangkan munggunakan skala yang telah di tentukan oleh developer. Data yang digunakan untuk menilai kepraktisan LKS ini menggunakan data kuantitatif yang meliputi 4 penelitian yaitu: tidak setuju, kurang setuju, setuju dan sagat setuju.

Tabel 2. Kriteria Kepraktisan Media Pembelajaran

\begin{tabular}{lll}
\hline Persentase (\%) & Kriteria Kepraktisan & Keterangan \\
\hline $80-100$ & Sangat Praktis & Tidak Revisi \\
$66-79$ & Praktis & Tidak Revisi \\
$56-65$ & Cukup Praktis & Revisi \\
$40-55$ & Kurang Praktis & Revisi \\
$30-39$ & Tidak Praktis & Revisi \\
\hline
\end{tabular}

\section{HASIL DAN PEMBAHASAN}

Dalam lembar kerja siswa berisi, halaman identitas halaman (materi, sub materi, alokasi waktu), standar kompetensi, tujuan pembelajaran, petujuk pengerjaan LKS, langkah kerja, materi pengantar dan contoh soal, latihan (berisi tiga soal agar memberi pemahaman materi kepada siswa), Dengan latihan soal siswa akan membangun pemahaman konsep; menghitung panjang segmen garis singgung persekutuan dalam dari dua lingkaran, menghitung panjang segmen garis singgung persekutuan luar dari dua lingkaran. Dalam hal ini siswa akan melakukan kegiatan yang utama yaitu meneliti, menanya, menalar, mengkomunikasikan, membaca (mencari informasi).

Berdasarkan tabel interpretasi dari hasil validator media sebesar $75 \%$ maka termasuk kedalam kategori valid. Untuk hasil tingkat validitas materi yaitu 67,5\% maka berdasarkan tabel tafsiran diatas termasuk valid dan tidak perlu revisi, tetapi peneliti melakukan revisi agar LKS menjadi sempurna.

\section{a. Penilaian keterlaksanaan LKS}

Berdasarkan uji coba yang telah dilakukan. Terlihat bahwa dalam melakukan penggunaan LKS dalam pembelajaran sangat praktis, penggunaan alokasi waktu yang efisien, siswa lebih mudah memanfaatkan dan mengerjakan latihan soal dalam lembar kerja siswa dan juga guru bisa membina murid dalam pembelajaran. Pertama kali pada waktu uji coba ada beberapa halangan yakni validator yang mengalami kesulitan memecahkan masalah dengan materi yang tercantum dalam buku. Setelah melakukan bebrapa kali revisi dan 
diujikan kembali hal ini terbukti efektif dan praktis. Terbukti dengan alokasi waktu yang dibutuhkan siswa dalam mengerjakan 3 soal.

b. Hasil Respon Siswa dan Respon Guru

Berdasarkan hasil penghitungan respon siswa diperoleh $86,9 \%$ maka hal ini dapat dikategorikan sangat praktis. Dari hasil perhitungan yang diperoleh dari respon guru diperoleh 72,3 \% maka hal ini dapat dikategorikan praktis menurut kriteria kepraktisan.

Sejalan dengan hal tersebut, meskipun hasil dari pengembangan LKS sudah termasuk valid dan praktis, tetapi peneliti masih memperbaiki LKS tersebut sesuai dengan kritik dan saran dari validator serta subjek yang telah di uji coba, hingga menghasilkan LKS yang berintegritas. Berikut hal-hal yang diperbaiki oleh peneliti sesuai dengan saran dari validator:

1. Merperbaiki judul

2. Memperbaiki tata letak

3. Menambahkan alokasi waktu pada identifikasi

4. Memperbaiki materi pengantar karena didalam materi pengantar belum ada materinya

5. Menambahkan contoh soal karena masih belum ada contoh soal dan pembahasan

Di dalam melaksanakan proses pembelajaran, dengan memakai pendekatan saintifik, memerlukan langkah-langkah sebagai berikut:

1. Mengamati

Dalam kegiatan mengamati lembar kerja siswa ini yakni masalah yang diamati yakni meliputi pokok bahasan garis singgung lingkaran yakni mengamati konsep garis singgung persekutuan dua lingkaran bagaian dalam dan luar.

2. Menanya

Menuntut siswa agar bertanya pada saat pembelajaran agar siswa juga dapat berpendapat

3. Mencoba

Aktivitas siswa dalam mencoba nampak saat pertemuan, ketika seoran murid melakukan aktivitas yang ada di LKS. Bahan ajar yang telah dikembangkan diberikan aktivitas kepada siswa yang dituntut untuk dilakulakukannya percobaan membaca dari sumber lain, meneliti objek/kejadian, kegiatan, dan wawancara dengan koresponden. 
4. Menalar

Aktivitas menalar bisa dari cara siswa dalam menyelesaikan pertanyaan yang diberikan, karena dengan diberikannya pertanyaan siswa di tuntut untuk dapat mengiterpresentasikan bermacam-macam ide dan sistematis dan berpikir logis untuk menjawab masalah yang di berikan.

5. Mengkomunikasikan

Kegiatan mengkomunikasikan dalam pengembangan bahan ajar lembar kerja siswa (LKS) merupakan tindakan dimana meminta siswa agar masalah yang ada di LKS yang sudah terselesaikan sehingga dapat disimpulkan. Kemudian dari setiap submateri siswa mebuat pengertian.

Pendekatan saintifik merupakan suatu cara dalam menciptakan pembelajaran yang bermakna. Menurut Fauziah (2013) dan Subakri \& Annizar (2021) pendekatan saintifik membawa seorang siswa dalam menginferensi persoalan yang ada pada hipotesis, gemar membaca, rasa ingin tahu, rasa peduli terhadap lingkungan. Siswa akan mendapat kesempatan dalam menyelidiki dan inkuiri serta menyajikan hasil karya dan mengembangkan pada saat pelaksanaanya. Melalui inkuiri siswa dan penyelidikan siswa dapat merangsang dalam berpikir secara kreatif, analisis, disiplin, berperilaku jujur dan mandiri. Aktivitas hasil karya tulis yang disajikan maka dapat menyebabkan sikap kreatif, amanah terhadap hasilnya, menghargai prestasi yang ada, berkomunikasi yang baik, memiliki kemampuan bekerjasama.

Menurut A. Machin (2014) dan Annizar, et al (2021) menggunakan pendekatan ilmiah atau saintifik saat pembelajaran di kelas sangat penting, sebab dapat memajukan bermacammacam kemampuan seperti keahlian dalam berkomunikasi berkomunikasi (communication skill), keahlian berpikir kritis (critical thinking skill), perilaku berkarakter, keahlian dalam bekerjasama serta penyelidikan (research and collaboration skill) sebab memberikan pengalaman belajar bisa mewujudkan keinginan dan manfaat pendidikan dalam memecahkan suatu masalah didalam aktivitas sehari- hari. Pendapat yang sama yakni menurut Dayanto (2014) yang mengatakan dalam menerapkan pendekatan saintifik yakni melibatkan keahlian proses sains.

\section{c. Keefektifan LKS}

Menurut pendapat Ainur (2016) Dalam mengembangkan hasil responden (siswa) merupakan hal yang dapat memperoleh keefektifan LKS, karena dari hasil tersebut dapat mengetahui murid aktif didalam pembelajaran. Skor hasil tes belajar siswa diperoleh 4 siswa atau $80 \%$ siswa dinyatakan tidak tuntas dan 2 siswa atau $20 \%$ siswa dinyatakan tuntas secara 
individual. Masih adanya murid yang masih di bawah KKM dimungkinkan pada waktu pembelajaran seorang murid masih belum mendalami pokok bahasan serta belum mengerti.

d. Pengembangan 4D

1. Tahap pendefinisian

Menganalisis siswa dan menganalisis pemahaman siswa.

2. Tahap perancangan

Produk awal yang akan dikembangkan oleh peneliti yaitu LKS.

3. Tahap pengembangan

Pada tahap ini LKS di validasi terlebih dahulu oleh para ahli untuk mengembangkan LKS .

\section{SIMPULAN DAN SARAN}

Berdasarkan dari hasil penelitian maka bisa ditarik kesimpulan yakni lembar kerja siswa yang sudah dikembangkan oleh peneliti secara umum memuat format yang meliputi judul LKS, identifikasi (materi, sub materi, kelas, semester, alokasi), tujuan pembelajaran, petunjuk pengerjaan, langkah kerja, materi pengantar, contoh soal, dan latihan soal. Dan hasil responden, serta hasil kevalidan yang dihasilkan dari validator, pengembangan LKS sudah mendekati integritas. Skor hasil tes belajar siswa yang diperoleh yaitu 4 siswa dinyatakan tidak tuntas dan 2 siswa dinyatakan tuntas secara individual. Dalam hal ini, masih ada siswa yang nilainya di bawah KKM, hal tersebut dikarenakan pada waktu pembelajaran siswa masih belum memahami pokok bahasan.

Setelah melakukan penelitian, menurut peneliti penelitian ini digunakan sebagai (1) menambah keahlian dan pemahaman seorang murid (2) menambah keahlian dalam berpiki kreatif murid (3) Di dalam pembelajaran diperlukan adanya pengembangan masalah masalah yang unik dan menantang minat siswa dalam mengamati dan memecahkan suatu masalah. (4) pembahasan pada lembar kerja siswa ini garis singgung lingkaran saja.

\section{DAFTAR PUSTAKA}

\section{Books:}

Dadek Arywiantari, A. A. Gede Agung, I Dewa Kode Tastra (2016), Pengembangan Multimedia Interaktif Model 4D Pada Pembelajaran IPA di SMP Negeri 3 Semarang, Universitas Pendidikan Ganesha Singaraja, Indonesia.

I Komang Suparsawan,S.Pd. (2020). Pendekatan Saintifik Dengan Model Pembelajaran STAD.Hal 15. 
Muhammad Fachri Baharuddin Paloloang (Tanpa tahun), Penerapan Model Problem Based Learning (PBL) Untuk Meningkatkan Hasil Belajar Siswa Pada Panjang Garis Singgung Dua Lingkaran Dikelas Viii Smp Negeri 19 Palu.

Sowanto, Bahan Ajar Pada Materi Garis Singgung Lingkaran Dengan Pendekatan Saintifik Untuk Siswa SMP, Sekolah Tinggi Ilmu Pendidikan (STKIP) Bima Ishaq Madeamin, Model Pengembangan Four-D.

\section{Online journal:}

Annizar, A. M. (2021, March). The effects of covid-19 in learning: effective and efficient online learning models of mathematical statistics and real analysis from the students' perspective. In Journal of Physics: Conference Series (Vol. 1836, No. 1, p. 012048). IOP Publishing.

Annizar, A. M. R., Lestari, A. C., Sofiah, S., Khairunnisa, G. F., \& Maulyda, M. A. (2020). Proses Berpikir Inkuiri Dalam Menyelesaikan Masalah Higher Order Thinking Skills (Hots) Ditinjau Dari Tingkat Kognitif. AKSIOMA: Jurnal Program Studi Pendidikan Matematika, 9(4), 1192-1204.

Annizar, A. M. R., \& Zahro, F. S. (2020). Proses Berpikir Metafora dalam Menyelesaikan Masalah Matematis Soal HOTS Berdasarkan Kemampuan Kognitif Siswa. Jurnal Tadris Matematika, 3(2), 117-130.

Annizar, A. M. R., \& Arifin, M. (2021). Perbedaan Prestasi Belajar Mahasiswa Ditinjau dari Jalur Seleksi Masuk Perguruan Tinggi. SAP (Susunan Artikel Pendidikan), 5(3).

Annizar, A. M., Lestari, A. C., Dalimarta, S., \& Wulandari, Y. N. (2021, March). The process of student analytical thinking in understanding and applying lattice method to solve mathematical problem. In Journal of Physics: Conference Series (Vol. 1836, No. 1, p. 012047). IOP Publishing.

A. Machin. (2014). Implementasi Pendekatan Saintifik, Penanaman Karakter Dan Konservasi Pada Pembelajaran Materi Pertumbuhan. Jurnal Pendidikan IPA Indonesia. 3 (1) $28-35$.

Dian Fitriana. (2016). Pengembangan Lembar Kerja Siswa Menggunakan Pendekatan Saintifik Untuk Melihat Berpikir Siswa Materi Perbandinga. Jurnal Pendidikan Matematika. 10 (2) 23 - 38.

Dwi Hidatanti. (2016). Pengembangan Lembar Kegiatan Siswa (LKS) Matematika Dengan Pendekatan Saintifik Pada Pokok Bahasan Garis Singgung Lingkaran Untuk Smp Kelas Viii. Jurnal Ilmiah Citra Bakti. 3 (1). 42 - 56. 
Hasratuddin. (2013). Membangun karakter melalui pembelajaran matematika. Jurnal Pendidikan Matematika PARADIKMA, 6(2) 130 - 141.

Kawiyah, Siti. (2015). Pengembangan Perangkat Pembelajaran Matematika Berbasis Saintifik Untuk Meningkatkan Kemampuan Pemecahan Masalah dan Prestasi Belajar Siswa. Pendidikan Matematika.10(2).

Magdalena, Maria, Zagoto Dan Oskah Dakhi. (2018). Pengembangan Perangkat Pembelajaran Matematika Peminatan Berbasis Pendekatan Saintifik Untuk Siswa Kela Ix Sekolah Menengah Atas. Jurnal Riview Pendidikan Dan Pengajaran.1(1).

Malalina, Pitriani, Dan Rika Firma Yenni. (2018). Active Knowledge Sharing Melalui LKS Berbasis Pendekatan Saintifik. Pendidikan Matematika.3(2).1-9.

Rusnilawati, R. (2016). Pengembangan Perangkat Pembelajaran Matematika Bercirikan Active Knowledge Sharing dengan Pendekatan Saintifik Kelas VIII. Riset Pendidikan Matematika.3(2).

Widiani, Tresia, M. Rif'at, Dan Romal Ijuddin. (2016). Penerapan Pendekatan Saintifik dan Pengaruhnya Terhadap Kemampuan Komunikasi Matematis dan Berpikir Kreatif Siswa. 5 (1).

Yustia,Via. (2015) .Peningkatan Kemampuan Pemecahan Masalah Melalui Pengembangan Lembar Kegiatan Siswa (LKS) dengan Pendekatan Saintifik. 64(1).

\section{Theses, Dissertation:}

Ainur Rohma. (2016). Keefektifan LKS Berbasis pendekatan saintifik pada submateri fotosintesis dan respirasi untuk melatih keterampilan proses terintegrasi. Berkala ilmiah Pendidikan Biologi 3 (5) 2302 - 9528. 